\title{
Elongation by Telomerase
}

National Cancer Institute

\section{Source}

National Cancer Institute. Elongation by Telomerase. NCI Thesaurus. Code C20341.

Most telomeres are maintained by telomerase. The enzymatic activity of telomerase lengthens terminal regions of eukaryotic telomeric DNA by RNA-templated addition of repeated DNA sequences to compensate for sequence loss as the cells divide.

Telomerase specifically elong ates the 3-prime end of a single-stranded overhang region on the G-rich 3-prime strand while the C-rich strand can be filled in by DNA polymerases. $(\mathrm{NCl})$ 